\title{
Enhanced Antioxidant Activity of Mugwort Herb and Vitamin C in Combination on Shelf-life of Chicken Nuggets
}

\author{
Ko-Eun Hwang, Hyun-Wook Kim, Dong-Heon Song, Yong-Jae Kim, Youn-Kyung Ham, \\ Yun-Sang Choi ${ }^{1}$, Mi-Ai Lee ${ }^{2}$, and Cheon-Jei Kim* \\ Department of Food Science and Biotechnology of Animal Resources, Konkuk University, Seoul 143-701, Korea \\ ${ }^{1}$ Research Group of Convergence Technology, Korean Food Research Institute, Seongnam 463-746, Korea \\ ${ }^{2}$ World Institute of Kimchi, An Annex of Korea Food Research Institute, Gwangju, 503-360, Korea
}

\begin{abstract}
The effect of mugwort extract (ME) and vitamin C (VC), added individually or in combination, on color, lipid oxidation, and sensory characteristics of chicken nuggets stored for $12 \mathrm{~d}$ was investigated. Eight treatments of chicken nuggets contained the following: Control (no antioxidant added), VC (0.05\% VC), ME $0.05(0.05 \% \mathrm{ME})$, ME $0.1(0.1 \% \mathrm{ME}), \mathrm{ME} 0.2$ $(0.2 \% \mathrm{ME}), \mathrm{VC}+\mathrm{ME} 0.05(0.05 \% \mathrm{VC}+0.05 \% \mathrm{ME})$ and $\mathrm{VC}+\mathrm{ME} 0.1(0.05 \% \mathrm{VC}+0.1 \% \mathrm{ME}), \mathrm{VC}+\mathrm{ME} 0.2(0.05 \% \mathrm{VC}+$ $0.2 \% \mathrm{ME}$ ). Results showed that the mixture of $0.05 \% \mathrm{VC}$ and $0.2 \% \mathrm{ME}$ was most effective for delaying lipid oxidation (thiobarbituric acid reactive substances, conjugated dienies, and peroxide formation) when compared to the control or ME alone added. The color values of all treatments were significantly affected by adding ME. Additionally, the total color difference $(\Delta E)$, chroma $\left(\mathrm{C}^{*}\right)$, and hue angle $\left(\mathrm{H}^{\circ}\right)$ values of all treatments, except for $\mathrm{VC}$, were lower than those of the control as the amount of ME increased. The sensory characteristics (flavor, odor, and overall acceptability) did not differ significantly in any of the chicken nugget samples, whereas storage time had a significant effect. The results suggest that the possibility of utilizing chicken nuggets with a mixture of mugwort extract and vitamin $\mathrm{C}$ for the increase of shelf-life and quality.
\end{abstract}

Keywords: antioxidant, mugwort, vitamin C, lipid oxidation, shelf-life, chicken nugget

\section{Introduction}

Worldwide consumption of chicken-based meat products has increased due to their nutritional quality. In fact, chicken meat supplies high protein (around $20 \mathrm{~g} / 100 \mathrm{~g}$ raw meat without skin) and low fat (about $5 \mathrm{~g} / 100 \mathrm{~g}$ raw meat without skin) (Bonoli et al., 2007). The increasing demand for processed chicken products such as sausage, meatballs, hamburgers, and nuggets has become a market trend. However, chicken meat is a highly perishable food; thus, its shelf-life must be optimized to meet marketing requirements (Sheu and Chen, 2002).

Lipid oxidation is the main cause of quality deterioration in meat and meat products. It is not only generates unacceptable off flavors and off odors, but also limits shelf-life and commercial stability. In contrast to raw meat in which lipid oxidation occurs over days or weeks,

*Corresponding author: Cheon-Jei Kim, Department of Food Science and Biotechnology of Animal Resources, Konkuk University, Seoul 143-701, Korea. Tel: +82-2-450-3684, Fax: +82-2-444-6695, E-mail: kimcj@konkuk.ac.kr these reactions proceed rapidly in cooked (i.e., fried) meats such that oxidized flavors are detectable within hours of cooking. In particular, thermal processes promote lipid oxidation by disrupting cell membranes and releasing pro-oxidants (Sampaio et al., 2012).

Many researchers have focused on developing fried food products with minimal quality deterioration due to an increased awareness of nutrition by consumers, and many approaches have been reported. Use of either synthetic or natural antioxidants is one of the major strategies for preventing lipid oxidation. Current recommendations restrict synthetic food additives, which encourage replacement by naturally occurring ingredients with similar functions. Apart from traditional antioxidants, a variety of compounds with oxidation inhibitory activity can be proposed for use in food. The desire for new sources of safe and inexpensive natural antioxidants has resulted in considerable interest in herbs and spices as natural antioxidant sources (Sampaio et al., 2012).

Mugwort (Artemisia princeps Pamp., family Carduaceae) is a natural herb plant used in tea, food, and traditional medicine in the East Asian countries of Korea, Ja- 
pan and China. This plant contains bioactive compounds such as phenolics, alkaloids, and vitamins $\mathrm{A}, \mathrm{B}_{1}, \mathrm{~B}_{2}$, and $\mathrm{C}$ as well as various minerals (Hwang et al., 2011).

Vitamin C (ascorbic acid) is a reducing agent, which increases shelf-life and stabilizes the color of meat and meat products. It has also been used in combination with other antioxidants by promoting their antioxidant effects (Djenane et al., 2002).

Until now, previous researches have reported that the beneficial effects of antioxidant combination to extend shelf-life reducing lipid oxidation. However, few studies have ever been done to examine the antioxidant combination effect of mugwort and other antioxidants in meat and meat products. Also, the evaluation of their effect in a range of food systems is still needed on successful application in meat and meat products. Therefore, the aim of this study was to investigate two different antioxidants, a mugwort extract (ME), vitamin $\mathrm{C}$ (VC) and their combination on shelf-life in chicken nuggets during $12 \mathrm{~d}$ of storage at $4^{\circ} \mathrm{C}$.

\section{Materials and Methods}

\section{Preparation of the mugwort extracts (ME)}

Commercial samples of dried mugwort were purchased from a local market. After separating the leaves from the dried mugwort, they were ground using a blender (KA2610, Jworld Tech, Korea) for $1 \mathrm{~min}$. Ten grams of finely ground using a blender (KA-2610, Jworld Tech, Korea) mugwort leaves were mixed with $200 \mathrm{~mL}$ of $50 \%$ ethanol; the leaves macerated solvent at room temperature (approximately $20^{\circ} \mathrm{C}$ ) for $24 \mathrm{~h}$ in a shaker (VS-8480, Vision Scientific Co., Ltd, Korea) at $50 \mathrm{rpm}$. The extracts were filtered through filter paper no. 1 (Whatman International, Maidstone, UK) and evaporated with a rotary evaporator (EYELA N-1000, Rikakikai, Japan) at $<50^{\circ} \mathrm{C}$. The products represented the ME.

\section{Preparation of the antioxidant treatments}

An antioxidant combination of vitamin C (VC; Sewoo Inc, Korea) and mugwort extract (ME; pH, 6.09 \pm 0.02 ; $\mathrm{L}^{*}$-value, $29.41 \pm 0.05 ; \mathrm{a}$-value, $1.49 \pm 0.26$; $\mathrm{b}^{*}$-value, 0.76 $\pm 0.04)$ was prepared according to the formulations: Control (no antioxidant added), VC $(0.05 \%$ vitamin $\mathrm{C}), \mathrm{ME}$ 0.05 (0.05\% mugwort extract), ME 0.1 ( $0.1 \%$ mugwort extract), ME 0.2 (0.2\% mugwort extract), $\mathrm{VC}+\mathrm{ME} 0.05$ $(0.05 \%$ vitamin $\mathrm{C}+0.05 \%$ mugwort extract $), \mathrm{VC}+\mathrm{ME}$ $0.1(0.05 \%$ vitamin $\mathrm{C}+0.1 \%$ mugwort extract), and $\mathrm{VC}$ $+\operatorname{ME} 0.2(0.05 \%$ vitamin $\mathrm{C}+0.2 \%$ mugwort extract $)$.

\section{Chicken meat and skin}

Fresh chicken breasts (Muscularis pectoralis) form fresh broilers (Arbor Acre strain, 5 wk of age, approximately $1.5-2.0 \mathrm{~kg}$ live weight) and chicken skin were obtained from a local meat market. The chicken breast and skin were ground using a meat grinder (PM-70, Mainca, Spain) equipped with an $8 \mathrm{~mm}$ plate. The ground tissue was then placed in Nylon/PE film, vacuum packaged using a vacuum packaging system (FJ-500XL, Fujee Tech, Korea), and stored at $0^{\circ} \mathrm{C}$ until required. Suitable amounts of the muscle and chicken skin were tempered at $4^{\circ} \mathrm{C}$ for $24 \mathrm{~h}$ prior to preparing the chicken nuggets.

\section{Preparation of the emulsion}

Chicken carcasses contain roughly $15 \%$ skin and $2-4 \%$ fat. Chicken skin without adipose tissue contains approximately 20-30\% fat (Sheu and Chen, 2002). In this study, chicken skin by-products were utilized as fat in the chicken nuggets. Chicken breast meat $(17 \%)$, chicken skin $(10 \%)$, ice $(3 \%)$, sodium chloride $(\mathrm{NaCl}, 1.5 \%)$, and sodium tripolyphosphate $(0.3 \%)$ were emulsified using silent cutter (Cutter Nr-963009, Hermann Scharfen GmbH \& Co, Germany).

\section{Processing of chicken nuggets}

After preparing the emulsion, each portion of ground chicken breast $(70 \%)$ meat was mixed with emulsion $(30 \%)$ and an antioxidant combination (see above section preparation of the antioxidant treatments). The mixture from each formulation was weighed to provide individual nugget pieces ( $40 \pm 1 \mathrm{~g}$ per piece). The samples were deep fried in soybean oil at $190 \pm 2^{\circ} \mathrm{C}$ for 5 min using a deep fryer (DHF520, Donghwa, Korea). The chicken nuggets were cooled by placing them on a rack at room temperature for $30 \mathrm{~min}$. The chicken nuggets were packaged refrigerated at $4^{\circ} \mathrm{C}$ and used for further analysis after 0,3 , 7 , and $12 \mathrm{~d}$.

\section{Instrumental color}

Color changes in the deep fried chicken nuggets during storage were monitored with a colorimeter (Chroma meter CR-210, Minolta, Japan) using an 8-mm diameter measuring area and a 50-mm diameter illumination area. Color was expressed with $L^{*}(100=$ white, $0=$ black $), a^{*}$ (positive $=$ redness, negative $=$ greenness $)$, and $b^{*}$ (positive $=$ yellowness, negative $=$ blueness) values. The colorimetric difference between a sample and a white standard reflectance plate, total color difference $(\Delta E)$, was calculated using the equation: $\Delta E=\left[\left(\mathrm{L}^{*}-\mathrm{L}\right)^{2}+(\mathrm{a} *-\mathrm{a})^{2}+\left(\mathrm{b}^{*}-\right.\right.$ 
b) $\left.)^{2}\right]^{1 / 2}\left(L^{*}=97.83, a^{*}=-0.43, b^{*}=+1.98\right)$. Additionally, the hue and chroma (saturation) values were determined using the formula, $\operatorname{Tan}^{-1}\left(\mathrm{~b}^{*} / \mathrm{a}^{*}\right)$ and $\left(\mathrm{a}^{2}+\mathrm{b}^{2}\right)^{1 / 2}$, respectively. Color readings were measured on ten randomly chosen spots on the chicken nuggets and were utilized as an estimate of meat discoloration.

\section{Lipid oxidation}

Lipid extraction was conducted as previously described (Folch et al., 1957) using a chloroform:methanol solvent system (2:1). Lipid extracts were evaporated and concentrated with a rotary evaporator (EYELA N-1000, Rikakikai. Co. Ltd., Japan), and the extracted lipids were used for the POV (peroxide value) and CD (conjugated diene) analyses. The POV of lipid extracted from the sample was analyzed according to Association of Official Analytical Chemists (AOAC) Oficial Methods 965.33 (AOAC, 2009).

$\mathrm{CD}$ were determined using a modified method adapted from Juntachote et al. (2006). Extracted sample lipids $(0.015 \mathrm{~g})$ were massed into a $25 \mathrm{~mL}$ volumetric flask, brought to volume with isooctane, and mixed. Absorbance was read at $234 \mathrm{~nm}$ with isooctane used as the blank. The $\mathrm{CD}$ concentration was calculated using a $25,000 \mathrm{M} / \mathrm{cm}$ molar extinction coefficient. Results are expressed as $\mu \mathrm{mol} / \mathrm{mg}$ meat sample lipids.

Lipid oxidation was assessed in sample triplicates using the 2-thiobarbituric acid (TBA) method of Tarladgis et al. (1960) with minor modifications and was expressed as miligrams of malondialdehyde (MA) per kilogram of sausage. A $10 \mathrm{~g}$ sample was blended with $50 \mathrm{~mL}$ distilled water for $2 \mathrm{~min}$ and then transferred to a distillation tube. The cup used for blending was washed with an additional $47.5 \mathrm{~mL}$ of distilled water, which was added to the same distillation flask with $2.5 \mathrm{~mL} 4 \mathrm{~N} \mathrm{HCl}$ and a few drops of antifoam agent (KMK-73, Shin-Etsu Silicone Co., Ltd., Korea). The mixture was distilled, and $50 \mathrm{~mL}$ of the distillate was collected. Five $\mathrm{mL}$ of $0.02 \mathrm{M}$ TBA in $90 \%$ acetic acid (TBA reagent) was added to test tubes containing $5 \mathrm{~mL}$ of the distillate and mixed well. The tubes were capped and heated in a boiling water bath for 30 min to develop the chromogen and cooled to room temperature. Absorbance was measured at $538 \mathrm{~nm}$ against a blank prepared with $5 \mathrm{~mL}$ distilled water and $5 \mathrm{~mL}$ TBA reagent using a UV/VIS spectrophotometer (Optizen 2120 UV plus, Mecasys Co. Ltd., Korea).

\section{Sensory evaluation}

Each chicken nugget was evaluated for flavor, odor, and overall acceptability on each day of sampling. The sensory evaluation was conducted by a 45 untrained members (acceptability test). Panelists (22 females, 23 males) were chosen among graduate students and faculty of the Department of Food Sciences and Biotechnology of Animal Resources, University of Konkuk using the following criteria: ages between 20 and 35, non-smokers, regular consumers of chicken products. The attributes which have been studied are the following: flavor, odor and overall acceptability using a 9-point hedonic rating scale (Lawless and Heymann, 1999). The panelists were instructed to clean their plate by consuming a cracker and sipping water between evaluations. The scale includes the following ranking: $1=$ extremely unacceptable, $2=$ very much unacceptable, $3=$ moderately unacceptable, $4=$ slightly unacceptable, $5=$ between acceptable and unacceptable, $6=$ slightly acceptable, $7=$ moderately acceptable, $8=$ very much acceptable and $9=$ extremely acceptable. A mean score of 7 or above indicates an acceptable product. A mean score below 5.0 marks the end of chicken nugget shelf-life (Mexis et al., 2009).

\section{Statistical analysis}

All data were subjected to the analysis of variance (ANOVA) using general linear model (GLM) procedure of SPSS 18.0 software (SPSS Inc., USA), with three replications, which was used as the storage periods $(0,3,7$, and $12 \mathrm{~d}$ ) and antioxidant type (Control, VC, ME 0.05, ME 0.1, ME 0.2, $\mathrm{VC}+\mathrm{ME} 0.05, \mathrm{VC}+\mathrm{ME} 0.1$, and $\mathrm{VC}+\mathrm{ME}$ 0.2 ). The Duncan's multiple range was applied for comparisons of means, differences were considered significant at $p<0.05$. The effects of antioxidant and storage on color, lipid oxidation, and sensory evaluation during refrigerated storage of chicken nugget were analyzed by two-way ANOVA with and storage as main factors. Correlations between variables were determined by correlation analyses using Pearson's linear correlation coefficient with the above statistical software package.

\section{Results and Discussion}

\section{Change in color values of chicken nuggets during storage}

The total color difference $(\Delta E)$, hue angle $\left(\mathrm{H}^{\circ}\right)$ and chroma $\left(\mathrm{C}^{*}\right)$ values of the chicken samples showed some significant differences in relation to the amount of ME added (Table 1). The formulations with ME had higher $\Delta E, \mathrm{H}^{\circ}$ and $\mathrm{C}^{*}$ values compared to that of the control. Higher $\Delta E$ value results showed a greater relative change 
Table 1. Effect of antioxidant combination on total color difference $(\Delta E)$, chroma $\left(C^{*}\right)$, and hue angles $\left(H^{\circ}\right)$ in chicken nugget during refrigerated storage for $12 \mathrm{~d}$

\begin{tabular}{|c|c|c|c|c|c|c|}
\hline \multirow{2}{*}{ Trait } & \multirow{2}{*}{ Treatment $^{1}$} & \multicolumn{4}{|c|}{ Storage period (d) } & \multirow{2}{*}{$\mathrm{SEM}^{2}$} \\
\hline & & 0 & 3 & 7 & 12 & \\
\hline \multirow{8}{*}{$\Delta E$} & Control & $41.00^{\mathrm{Ca}}$ & $39.59^{\mathrm{Eb}}$ & $38.25^{\mathrm{Ec}}$ & $35.30^{\mathrm{Ed}}$ & 0.398 \\
\hline & $\mathrm{VC}$ & $37.92^{\mathrm{Da}}$ & $36.97^{\mathrm{Db}}$ & $35.66^{\mathrm{Dc}}$ & $32.97^{\mathrm{Dd}}$ & 0.366 \\
\hline & ME 0.05 & $41.19^{\mathrm{Ca}}$ & $40.39^{\mathrm{Ca}}$ & $39.31^{\mathrm{Cb}}$ & $36.37^{\mathrm{Cc}}$ & 0.358 \\
\hline & ME 0.1 & $43.28^{\mathrm{Ba}}$ & $42.59^{\mathrm{Ba}}$ & $41.07^{\mathrm{Bb}}$ & $38.98^{\mathrm{Bc}}$ & 0.328 \\
\hline & ME 0.2 & $45.49^{\mathrm{Aa}}$ & $44.05^{\mathrm{Ab}}$ & $43.16^{\mathrm{Ac}}$ & $40.33^{\mathrm{Ad}}$ & 0.358 \\
\hline & $\mathrm{VC}+\mathrm{ME} 0.05$ & $41.80^{\mathrm{Ca}}$ & $40.66^{\mathrm{Ca}}$ & $39.56^{\mathrm{Cb}}$ & $37.15^{\mathrm{Cc}}$ & 0.330 \\
\hline & $\mathrm{VC}+\mathrm{ME} 0.1$ & $42.95^{\mathrm{Ba}}$ & $42.01^{\mathrm{Bb}}$ & $41.06^{\mathrm{Bc}}$ & $38.22^{\mathrm{Bd}}$ & 0.335 \\
\hline & $\mathrm{VC}+\mathrm{ME} 0.2$ & $45.09^{\mathrm{Aa}}$ & $44.44^{\mathrm{Ab}}$ & $43.41^{\mathrm{Ac}}$ & $40.39^{\mathrm{Ad}}$ & 0.354 \\
\hline & & 0.307 & 0.304 & 0.313 & 0.318 & \\
\hline \multirow{8}{*}{$\mathrm{C}^{*}$} & Control & $33.70^{\mathrm{Dd}}$ & $36.93^{\mathrm{Dc}}$ & $39.94^{\mathrm{Cb}}$ & $42.09^{\mathrm{Ca}}$ & 0.621 \\
\hline & $\mathrm{VC}$ & $31.62^{\mathrm{Dd}}$ & $34.95^{\mathrm{Ec}}$ & $37.86^{\mathrm{Db}}$ & $40.02^{\mathrm{Da}}$ & 0.620 \\
\hline & ME 0.05 & $34.58^{\mathrm{Cc}}$ & $37.37^{\mathrm{Db}}$ & $40.74^{\mathrm{Ca}}$ & $42.10^{\mathrm{Ca}}$ & 0.582 \\
\hline & ME 0.1 & $38.19^{\mathrm{Bd}}$ & $40.73^{\mathrm{Bc}}$ & $43.91^{\mathrm{Bb}}$ & $45.77^{\mathrm{Ba}}$ & 0.544 \\
\hline & ME 0.2 & $40.23^{\mathrm{Ad}}$ & $42.40^{\mathrm{Ac}}$ & $45.75^{\mathrm{Ab}}$ & $47.25^{\mathrm{Aa}}$ & 0.541 \\
\hline & $\mathrm{VC}+\mathrm{ME} 0.05$ & $35.06^{\mathrm{Cd}}$ & $37.26^{\mathrm{Dc}}$ & $40.13^{\mathrm{Cb}}$ & $42.12^{\mathrm{Ca}}$ & 0.548 \\
\hline & VC+ME 0.1 & $34.89^{\mathrm{Bd}}$ & $35.78^{\mathrm{Ec}}$ & $38.30^{\mathrm{Db}}$ & $40.55^{\mathrm{Da}}$ & 0.473 \\
\hline & $\mathrm{VC}+\mathrm{ME} 0.2$ & $37.47^{\mathrm{Ac}}$ & $38.62^{\mathrm{Cc}}$ & $40.85^{\mathrm{Cb}}$ & $42.54^{\mathrm{Ca}}$ & 0.389 \\
\hline & & 0.391 & 0.317 & 0.340 & 0.335 & \\
\hline \multirow{8}{*}{$\mathrm{H}^{\circ}$} & Control & $81.74^{\mathrm{Dd}}$ & $82.91^{\mathrm{Dc}}$ & $84.78^{\mathrm{Cb}}$ & $86.29^{\mathrm{Ba}}$ & 0.327 \\
\hline & $\mathrm{VC}$ & $81.27^{\mathrm{Dd}}$ & $82.58^{\mathrm{Dc}}$ & $84.70^{\mathrm{Cb}}$ & $85.59^{\mathrm{Ca}}$ & 0.320 \\
\hline & ME 0.05 & $82.67^{\mathrm{Cc}}$ & $83.48^{\mathrm{Cc}}$ & $85.79^{\mathrm{Bb}}$ & $86.54^{\mathrm{Ba}}$ & 0.302 \\
\hline & ME 0.1 & $84.05^{\mathrm{Bc}}$ & $84.43^{\mathrm{Bc}}$ & $85.62^{\mathrm{Bb}}$ & $86.59^{\mathrm{Ba}}$ & 0.209 \\
\hline & ME 0.2 & $85.25^{\mathrm{Ab}}$ & $85.22^{\mathrm{Ab}}$ & $86.87^{\mathrm{Aa}}$ & $87.86^{\mathrm{Aa}}$ & 0.226 \\
\hline & $\mathrm{VC}+\mathrm{ME} 0.05$ & $82.82^{\mathrm{Cc}}$ & $82.89^{\mathrm{Dc}}$ & $84.62^{\mathrm{Cb}}$ & $85.64^{\mathrm{Ca}}$ & 0.237 \\
\hline & $\mathrm{VC}+\mathrm{ME} 0.1$ & $83.93^{\mathrm{Bc}}$ & $84.03^{\mathrm{Bc}}$ & $85.89^{\mathrm{Bb}}$ & $86.73^{\mathrm{Ba}}$ & 0.240 \\
\hline & $\mathrm{VC}+\mathrm{ME} 0.2$ & $85.17^{\mathrm{Ac}}$ & $85.09^{\mathrm{Ac}}$ & $86.89^{\mathrm{Ab}}$ & $87.51^{\mathrm{Aa}}$ & 0.220 \\
\hline \multicolumn{2}{|c|}{$\mathrm{SEM}^{2}$} & 0.194 & 0.130 & 0.135 & 0.114 & \\
\hline
\end{tabular}

${ }^{1}$ Control: no antioxidant, VC: vitamin C $0.05 \%$, ME 0.05: mugwort extract 0.05\%, ME 0.1: mugwort extract 0.1\%, ME 0.2: mugwort extract $0.2 \%$, $\mathrm{VC}+\mathrm{ME} 0.05$ : vitamin $\mathrm{C} 0.05 \%$ and mugwort extract $0.05 \%$, VC+ME 0.1 : vitamin $\mathrm{C} 0.05 \%$ and mugwort extract $0.1 \%$, $\mathrm{VC}+\mathrm{ME}$ 0.2: vitamin $\mathrm{C} 0.05 \%$ and mugwort extract $0.2 \%$.

${ }^{2}$ SEM: Standard error of the mean $(n=30)$.

Means with different superscripts are significantly different $(p<0.05)$.

A-E Antioxidant effects.

${ }^{\mathrm{a}-\mathrm{d}}$ Storage day effects.

in color compared to the meat's original color. Similar results were observed in frankfurters when fat was replaced with peach dietary fiber concentrate, which showed increased $\Delta E$ values (Grigelmo et al., 1999). Also, LópezLópez et al. (2009) reported that the $\mathrm{C}^{*}$ values of cooked sausages were significantly affected by adding olive and other vegetable oils. Choi et al. (2011) found that pork batter formulated with rice bran fiber had higher $\mathrm{H}^{\circ}$ values with increasing rice bran fiber level than that in the control $(p<0.05)$. Additionally, the $\mathrm{H}^{\circ}$ values explains the hue in meat, redness at $0^{\circ}$ and yellow when the angle was increased to $90^{\circ}$, whereas simultaneously increasing $\mathrm{H}^{\circ}$ and $\mathrm{C}^{*}$ values showed that the meat became more orange and brighter in color (Luciano et al., 2009). In agreement with this trends, increase in $\mathrm{C}^{*}$ and $\mathrm{H}^{\circ}$ values, regardless of the antioxidant treatment was found. However, the antioxidant treatment affected this color parameter due to brownish color of ME, which was likely transferred to the sample, causing a modification of the chicken nugget color. Liz et al. (2013) recommended that some natural ingredients, which possessing the specific color, lead to discoloration of finished meat products.

\section{Change in lipid oxidation of chicken nuggets dur- ing storage}

Concentrations of initial oxidation products (POV and $\mathrm{CD}$ ) in the lipid fraction of the chicken nugget together with those of MA (malondialdehyde) during the $12 \mathrm{~d}$ storage period are presented in Table 2 and Fig. 1 and 2. The POV and $\mathrm{CD}$ values in the control and VC treatment 
Table 2. Effect of antioxidant combination on CD $(\mu \mathrm{mol} / \mathrm{mg}$ lipid) in chicken nugget during refrigerated storage for $12 \mathrm{~d}$

\begin{tabular}{|c|c|c|c|c|c|}
\hline \multirow{2}{*}{ Treatment $^{1}$} & \multicolumn{4}{|c|}{ Storage period $(\mathrm{d})$} & \multirow{2}{*}{$\mathrm{SEM}^{2}$} \\
\hline & 0 & 3 & 7 & 12 & \\
\hline Control & $0.640^{\mathrm{Ad}}$ & $0.768^{\mathrm{Aa}}$ & $0.728^{\mathrm{Ab}}$ & $0.676^{\mathrm{Cc}}$ & 0.009 \\
\hline $\mathrm{VC}$ & $0.631^{\mathrm{Ad}}$ & $0.743^{\mathrm{Ba}}$ & $0.694^{\mathrm{Bb}}$ & $0.653^{\mathrm{Dc}}$ & 0.008 \\
\hline ME 0.05 & $0.610^{\mathrm{Bd}}$ & $0.734^{\mathrm{Ba}}$ & $0.673^{\mathrm{Cb}}$ & $0.645^{\mathrm{Dc}}$ & 0.009 \\
\hline ME 0.1 & $0.598^{\mathrm{Bc}}$ & $0.701^{\mathrm{Ca}}$ & $0.753^{\mathrm{Db}}$ & $0.709^{\mathrm{Ba}}$ & 0.011 \\
\hline ME 0.2 & $0.575^{\mathrm{Cc}}$ & $0.675^{\mathrm{Db}}$ & $0.719^{\mathrm{Aa}}$ & $0.678^{\mathrm{Cb}}$ & 0.010 \\
\hline $\mathrm{VC}+\mathrm{ME} 0.05$ & $0.572^{\mathrm{Cc}}$ & $0.646^{\mathrm{Eb}}$ & $0.691^{\mathrm{Ba}}$ & $0.654^{\mathrm{Db}}$ & 0.008 \\
\hline $\mathrm{VC}+\mathrm{ME} 0.1$ & $0.566^{\mathrm{Cd}}$ & $0.627^{\mathrm{Fc}}$ & $0.675^{\mathrm{Cb}}$ & $0.754^{\mathrm{Aa}}$ & 0.013 \\
\hline $\mathrm{VC}+\mathrm{ME} 0.2$ & $0.560^{\mathrm{Cd}}$ & $0.598^{\mathrm{Gc}}$ & $0.654^{\mathrm{Db}}$ & $0.712^{\mathrm{Ba}}$ & 0.011 \\
\hline $\mathrm{SEM}^{2}$ & 0.004 & 0.007 & 0.004 & 0.005 & \\
\hline
\end{tabular}

${ }^{1}$ Treatments are the same as in Table 1.

${ }^{2}$ SEM: Standard error of the mean $(n=8)$.

Means with different superscripts are significantly different $(p<0.05)$.

A-G Antioxidant effects.

${ }^{\mathrm{a}-\mathrm{d}}$ Storage day effects.

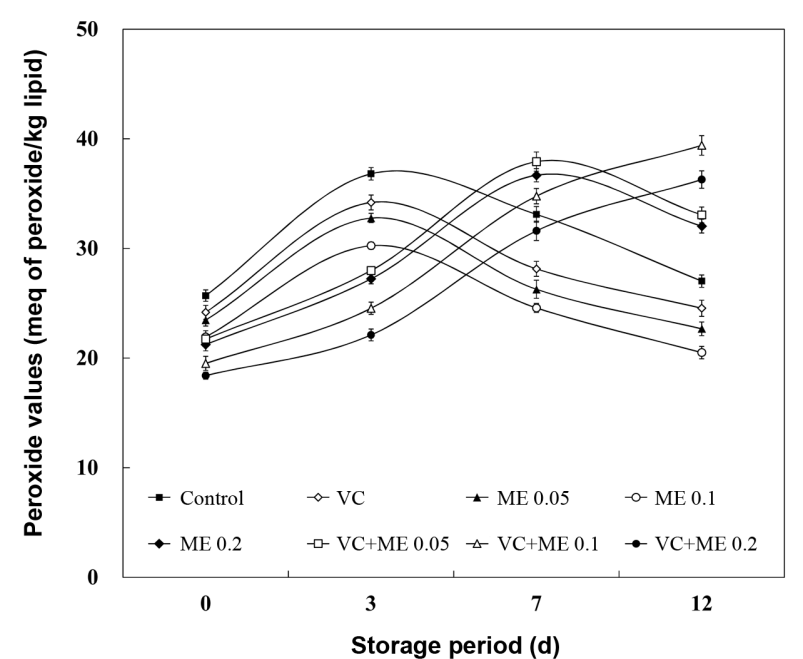

Fig. 1. Effect of antioxidant combination on POV (meq of active $\mathrm{O}_{2} / \mathrm{kg}$ lipid) in chicken nugget during refrigerated storage for $12 \mathrm{~d}$. Error bar represents the standard error of the mean for each treatment $(n=8)$. ( $\boldsymbol{\square})$ Control: no antioxidant, $(\diamond)$ VC: vitamin C $0.05 \%$, ( $\bullet$ ) ME 0.05 : mugwort extract $0.05 \%$, $(\bigcirc)$ ME 0.1 : mugwort extract $0.1 \%,(\diamond)$ ME 0.2 : mugwort extract $0.2 \%,(\square) \mathrm{VC}+\mathrm{ME}$ 0.05: vitamin C $0.05 \%$ and mugwort extract $0.05 \%,(\triangle)$ $\mathrm{VC}+\mathrm{ME}$ 0.1: vitamin C $0.05 \%$ and mugwort extract $0.1 \%$, ( ) $\mathrm{AC}+\mathrm{ME} 0.2$ : vitamin $\mathrm{C} 0.05 \%$ and mugwort extract $0.2 \%$.

was more intense compared to the ME alone and/or combination $\mathrm{VC}$; maximum values for POV and $\mathrm{CD}$ contents were reached on $3 \mathrm{~d}$, after which a decline was observed. The POV changes over time agree with the mechanism of lipid oxidation, which is a dynamic three-stage process. During the initial stage of oxidation, the increase was probably due to the faster rate of formation of new hydroperoxides than degradation of hydroperoxides into sec-

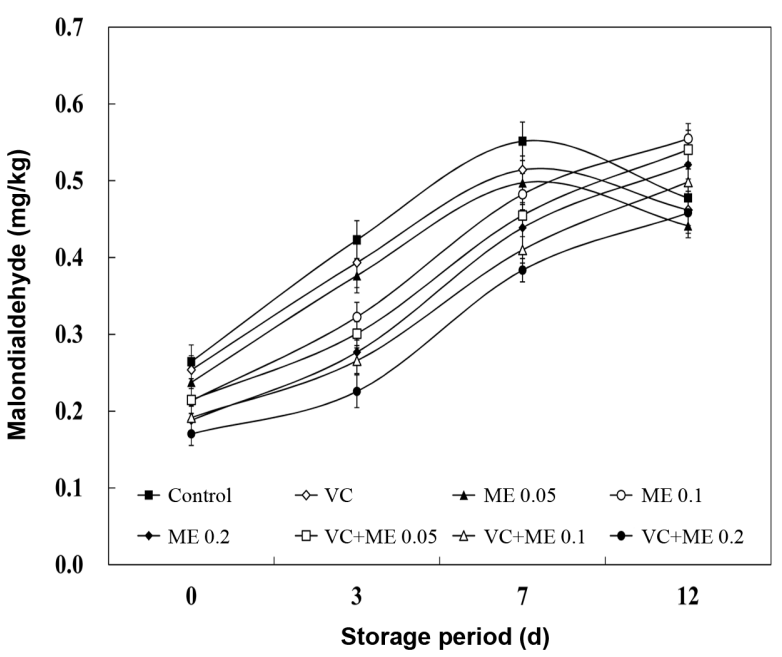

Fig. 2. Effect of antioxidant combination on TBARS values (mg MA/kg) in chicken nugget during refrigerated storage for $12 \mathrm{~d}$. Error bar represents the standard error of the mean for each treatment $(n=8)$. Treatments are the same as in Fig. 1.

ondary oxidation products. Decomposition of hydroperoxides into secondary products increases at a higher rate as lipid oxidation proceeds, as compared to the formation of new hydroperoxides, resulting in decreased POV (Qi and Zhou, 2013). Also, Sampaio et al. (2012) observed in increase of $\mathrm{CD}$ of chicken meat treated with antioxidant combination (oregano, sage, and honey) during $48 \mathrm{~h}$, followed by a decrease thereafter due to conjugated hydroperoxides breaking down into secondary lipid oxidation products.

In contrast to POV and CD, TBARS values represent the content of secondary products as measured by MA con- 
centration (Hassan and Fan, 2005). The samples treated with Control, VC, and ME 0.05 an increasing trend in TBARS values until $7 \mathrm{~d}$ followed by a decrease until 12 d of storage was observed. According to Melton (1983), although MA is a secondary lipid oxidation product, it does not necessarily mean that TBARS continues to increase throughout storage. These low TBARS numbers are thought to be the result of MA reactions with proteins. Chouliara et al. (2007) reported similar findings that the TBARS values in chicken breast meat treated with oregano oil and modified atmosphere packaging increased during $12 \mathrm{~d}$ of storage and then later decreased. In this study, the VC treatment did not exhibit antioxidant activity compared to that of other treated samples. SánchezEscalante et al. (2003) reported that adding 500 ppm vitamin $\mathrm{C}$ was ineffective for inhibiting lipid oxidation, and even caused a pro-oxidant effect. However, the mixture $\mathrm{VC}$ and the ME, except for $\mathrm{VC}+\mathrm{ME} 0.05$, exhibited the lowest values for all oxidation products measured than those containing individual ME, a finding that demonstrates a synergistic effect to reduce lipid oxidation. Djenane et al. (2002) suggested that vitamin C roles synergistically in antioxidation when combined with other antioxidants by enhancing their antioxidant ability. The antioxidant ability of the ME could be due to presence of natural antioxidants. Kim (2011) reported that mugwort contains many ingredients with antioxidant and antimicrobial properties such as polyphenols, and a relationship between phenolic content and antioxidant capacity has been observed (Velioglu et al., 1998). Previous study indicated that phenolic compounds prevent degradation to more active oxidizing forms, such as MA and have abilities to seques-

Table 3. Effect of antioxidant combination on sensory evaluation in chicken nugget during refrigerated storage for $12 \mathrm{~d}$

\begin{tabular}{|c|c|c|c|c|c|c|}
\hline \multirow{2}{*}{ Trait $^{1}$} & \multirow{2}{*}{ Treatment $^{2}$} & \multicolumn{4}{|c|}{ Storage period $(\mathrm{d})$} & \multirow{2}{*}{$\mathrm{SEM}^{3}$} \\
\hline & & 0 & 3 & 7 & 12 & \\
\hline \multirow{8}{*}{ Flavor } & Control & $8.36^{\mathrm{a}}$ & $8.17^{\mathrm{ab}}$ & $7.89^{b}$ & $7.00^{\mathrm{c}}$ & 0.105 \\
\hline & $\mathrm{VC}$ & $8.27^{\mathrm{a}}$ & $8.06^{\mathrm{a}}$ & $7.94^{\mathrm{a}}$ & $7.05^{\mathrm{b}}$ & 0.100 \\
\hline & ME 0.05 & $8.41^{\mathrm{a}}$ & $8.00^{\mathrm{ab}}$ & $7.72^{b}$ & $7.05^{\mathrm{c}}$ & 0.113 \\
\hline & ME 0.1 & $8.45^{\mathrm{a}}$ & $8.33^{\mathrm{a}}$ & $7.94^{\mathrm{b}}$ & $7.00^{\mathrm{c}}$ & 0.113 \\
\hline & ME 0.2 & $8.23^{\mathrm{a}}$ & $8.22^{\mathrm{a}}$ & $7.89^{\mathrm{a}}$ & $7.09^{c}$ & 0.101 \\
\hline & $\mathrm{VC}+\mathrm{ME} 0.05$ & $8.55^{\mathrm{a}}$ & $8.22^{\mathrm{ab}}$ & $7.96^{\mathrm{b}}$ & $7.16^{\mathrm{c}}$ & 0.114 \\
\hline & $\mathrm{VC}+\mathrm{ME} 0.1$ & $8.32^{\mathrm{a}}$ & $8.11^{\mathrm{a}}$ & $7.56^{\mathrm{b}}$ & $7.20^{\mathrm{b}}$ & 0.092 \\
\hline & $\mathrm{VC}+\mathrm{ME} 0.2$ & $8.36^{\mathrm{a}}$ & $8.28^{\mathrm{ab}}$ & $8.00^{\mathrm{b}}$ & $7.23^{\mathrm{c}}$ & 0.093 \\
\hline \multicolumn{2}{|c|}{$\mathrm{SEM}^{3}$} & 0.050 & 0.043 & 0.054 & 0.045 & \\
\hline \multirow{8}{*}{ Odor } & Control & $8.64^{\mathrm{a}}$ & $8.36^{\mathrm{a}}$ & $7.61^{b}$ & $7.09^{c}$ & 0.128 \\
\hline & $\mathrm{VC}$ & $8.36^{\mathrm{a}}$ & $8.45^{\mathrm{a}}$ & $7.72^{b}$ & $7.05^{\mathrm{c}}$ & 0.124 \\
\hline & ME 0.05 & $8.55^{\mathrm{a}}$ & $8.27^{\mathrm{a}}$ & $7.44^{\mathrm{b}}$ & $7.00^{\mathrm{c}}$ & 0.131 \\
\hline & ME 0.1 & $8.32^{\mathrm{a}}$ & $8.41^{\mathrm{a}}$ & $7.83^{b}$ & $7.10^{\mathrm{c}}$ & 0.102 \\
\hline & ME 0.2 & $8.48^{\mathrm{a}}$ & $8.27^{\mathrm{a}}$ & $7.78^{b}$ & $7.15^{\mathrm{c}}$ & 0.101 \\
\hline & $\mathrm{VC}+\mathrm{ME} 0.05$ & $8.18^{\mathrm{a}}$ & $8.23^{\mathrm{a}}$ & $7.78^{b}$ & $7.27^{\mathrm{c}}$ & 0.085 \\
\hline & $\mathrm{VC}+\mathrm{ME} 0.1$ & $8.59^{\mathrm{a}}$ & $8.18^{\mathrm{ab}}$ & $7.61^{b}$ & $7.25^{\mathrm{d}}$ & 0.105 \\
\hline & $\mathrm{VC}+\mathrm{ME} 0.2$ & $8.27^{\mathrm{a}}$ & $8.18^{\mathrm{a}}$ & $7.67^{\mathrm{b}}$ & $7.32^{\mathrm{c}}$ & 0.089 \\
\hline \multicolumn{2}{|c|}{$\mathrm{SEM}^{3}$} & 0.052 & 0.056 & 0.059 & 0.046 & \\
\hline \multirow{8}{*}{$\begin{array}{c}\text { Overall } \\
\text { acceptability }\end{array}$} & Control & $8.50^{\mathrm{a}}$ & $8.11^{\mathrm{a}}$ & $7.67^{b}$ & $6.87^{\mathrm{c}}$ & 0.123 \\
\hline & $\mathrm{VC}$ & $8.41^{\mathrm{a}}$ & $8.22^{\mathrm{ab}}$ & $7.78^{\mathrm{b}}$ & $6.91^{\mathrm{c}}$ & 0.135 \\
\hline & ME 0.05 & $8.45^{\mathrm{a}}$ & $8.17^{\mathrm{ab}}$ & $7.83^{b}$ & $6.98^{c}$ & 0.120 \\
\hline & ME 0.1 & $8.55^{\mathrm{a}}$ & $8.44^{\mathrm{a}}$ & $7.89^{b}$ & $7.00^{\mathrm{c}}$ & 0.124 \\
\hline & ME 0.2 & $8.36^{\mathrm{a}}$ & $8.28^{\mathrm{a}}$ & $7.67^{\mathrm{b}}$ & $7.04^{\mathrm{c}}$ & 0.114 \\
\hline & $\mathrm{VC}+\mathrm{ME} 0.05$ & $8.23^{\mathrm{a}}$ & $8.33^{\mathrm{ab}}$ & $7.94^{b}$ & $7.36^{\mathrm{c}}$ & 0.093 \\
\hline & $\mathrm{VC}+\mathrm{ME} 0.1$ & $8.36^{\mathrm{a}}$ & $8.17^{\mathrm{ab}}$ & $7.89^{b}$ & $7.27^{\mathrm{c}}$ & 0.097 \\
\hline & $\mathrm{VC}+\mathrm{ME} 0.2$ & $8.32^{\mathrm{a}}$ & $8.22^{\mathrm{a}}$ & $7.91^{\mathrm{b}}$ & $7.23^{\mathrm{c}}$ & 0.088 \\
\hline \multicolumn{2}{|c|}{ SEM $^{3}$} & 0.055 & 0.065 & 0.051 & 0.042 & \\
\hline
\end{tabular}

${ }_{1}^{1}$ Sensory score: $1=$ extremely unacceptable, $2=$ very much unacceptable, $3=$ moderately unacceptable, $4=$ slightly unacceptable, $5=$ between acceptable and unacceptable, $6=$ s lightly acceptable, $7=$ moderately acceptable, $8=$ very much acceptable and $9=$ extremely acceptable. A mean score of 7 or above indicates an acceptable product. A mean score below 5.0 marks the end of chicken nugget shelf-life.

${ }^{2}$ Treatments are the same as in Table 1 .

${ }^{3}$ SEM: Standard error of the mean $(n=4)$.

Means with different superscripts are significantly different $(p<0.05)$.

${ }^{\mathrm{a}-\mathrm{d}}$ Storage day effects. 
trate radicals, and chelate metals (Baydar et al., 2004). In summary, the results displayed that the best antioxidative effect $(p<0.05)$ was obtained with the combination of VC $+\mathrm{ME} 0.2(0.05 \%$ vitamin $\mathrm{C}+0.2 \%$ mugwort extracts), for which the values of lipid oxidation (POV, CD, and TBARS) were lower at the end of storage period (12 d) than those of the control. Results are in accordance with those of Djenane et al. (2002), who recommended that antioxidant combinations are regarded to be more effective than single antioxidant because when antioxidants are combined they support each other synergistically to create an expanded effect.

\section{Change in sensory evaluation of chicken nuggets during storage}

Sensory scores for the flavor, odor, and overall acceptability of chicken nuggets containing the ME (either alone or with VC) did not significantly affect the flavor, odor, or overall acceptability scores, whereas a significant effect from storage time was noted (Table 3). The chicken samples stored for $12 \mathrm{~d}$ with the antioxidant combination showed higher scores, although the average values for overall acceptance were not different $(p>0.05)$ among treatments. These results agree with those of Carpenter et al. (2007) for cooked pork patties supplemented with grape seed and blackberry, where the sensory properties were not diminished. Naveena et al. (2008) indicated that adding pomegranate juice and rind powder to chicken patties did not impart a significant difference in the sensory evaluation (off-odor, sweet flavor, chicken flavor, and overall palatability score). Furthermore, according to Nassu et al.
(2003), the end of the shelf-life of a product is considered when there is a lowering of 1.5 points on the hedonic scale. As storage time increased, sensory evaluations had lower scores than those of the initial storage period.

\section{Correlation coefficients among different parame- ters for all chicken nuggets during storage}

Our present study showed that the negatively correlation coefficients were found between TBARS values and sensory evaluation, such as flavor, odor, and overall acceptability $\left(\mathrm{R}^{2}=0.795,0.807\right.$, and 0.798 respectively) (Table 4). These data agree with those of Donald (1998), who proposed that the TBARS value had been widely used for measuring secondary lipid oxidation products, mainly aldehydes, which contribute to off-flavors in oxidised meat and meat matrix. Therefore, this method demonstrated good correlation with the sensory quality of foods. Sánchez-Escalante et al. (2003) reported that deterioration was related to oxidative processes and not spoilage due to microorganism growth. According to Campo et al. (2006), meat products can be considered well preserved in regards to oxidative changes, when they had $2 \mathrm{mg} \mathrm{MA} / \mathrm{kg}$ meat as a threshold value for rancidity perception by consumers. The TBARS values of all chicken nugget samples did not exceed $0.6 \mathrm{mg} \mathrm{MA} / \mathrm{kg}$ by the end of the storage period (Fig. 2).

\section{Conclusion}

The antioxidant combination demonstrate the positive effects on retarding lipid oxidation compared to that of

Table 4. $p$-values of both factors (Treatment: $T$ and Storage: $S$ ) and interaction $(T * S)$, and correlation coefficients of among different parameters for all chicken nuggets during refrigerated storage for $12 \mathrm{~d}$

\begin{tabular}{|c|c|c|c|c|c|c|c|c|c|}
\hline & $\Delta E^{1}$ & $\mathrm{H}^{\circ}$ & $\mathrm{C}^{*}$ & POV & $\mathrm{CD}$ & TBARS & Flavor & Odor & $\begin{array}{c}\text { Overall } \\
\text { acceptability }\end{array}$ \\
\hline Treatment & $* * *$ & $* * *$ & $* * *$ & $* * *$ & $* * *$ & $* * *$ & $*$ & NS & $\mathrm{NS}$ \\
\hline Storage & $* * *$ & $* * *$ & $* * *$ & $* * *$ & $* * *$ & $* * *$ & $* * *$ & $* * *$ & $* * *$ \\
\hline Treatment*Storage & $* * *$ & $* * *$ & NS & $* * *$ & $* * *$ & $* * *$ & NS & NS & NS \\
\hline$\Delta E$ & 1.000 & & & & & & & & \\
\hline $\mathrm{H}^{\circ}$ & 0.037 & 1.000 & & & & & & & \\
\hline $\mathrm{C}^{*}$ & 0.041 & $0.880^{* *}$ & 1.000 & & & & & & \\
\hline POV & 0.245 & 0.226 & 0.248 & 1.000 & & & & & \\
\hline $\mathrm{CD}$ & $0.045^{*}$ & 0.209 & $0.383^{*}$ & $0.741 * *$ & 1.000 & & & & \\
\hline TBARS & $0.665^{* *}$ & $0.561 * *$ & $0.631 * *$ & $0.573 * *$ & $0.736^{* *}$ & 1.000 & & & \\
\hline Flavor & $0.638 * *$ & $0.714 * *$ & $0.653 * *$ & 0.304 & $0.388^{*}$ & $0.795^{* *}$ & 1.000 & & \\
\hline Odor & $0.597 * *$ & $0.777 * *$ & $0.683 * *$ & 0.274 & 0.320 & $0.807 * *$ & $0.929 * *$ & 1.000 & \\
\hline Overall acceptability & $0.649 * *$ & $0.734 * *$ & $0.672 * *$ & 0.270 & $0.361^{*}$ & $0.798 * *$ & $0.965 * *$ & $0.956 * *$ & 1.000 \\
\hline
\end{tabular}

$p$-values: $\mathrm{ns}=p>0.05, * p<0.05, * * p<0.01, * * * p<0.001$.

Correlation coefficients: * indicates significance at $p<0.05 ; * *$ indicates significance at $p<0.01$.

${ }^{1} \Delta E$, total color difference; $\mathrm{H}^{\circ}$, hue angle; $\mathrm{C}^{*}$, chroma value; $\mathrm{POV}$, peroxide value; $\mathrm{CD}$, conjugated diene; TBARS, thiobarbituric acid reactive substance; Flavor, Odor, Overall acceptability, sensory characteristic 
control and mugwort extract alone added in chicken nugget. Among the antioxidant combination, $\mathrm{VC}+\mathrm{ME} 0.2$ $(0.05 \%$ vitamin $\mathrm{C}+0.2 \%$ mugwort extract) had significantly lower POV, CD, and MA concentrations during refrigerated storage for $12 \mathrm{~d}$. Although, the investigation of antioxidant combination in a range of food processing systems is still needed for successful application in meat and meat products. The development of prevention strategies using antioxidant combination deserves more attention. The results demonstrated that combination with mugwort extract and vitamin $\mathrm{C}$ showed the potential as alternatives to commercial antioxidants, for increasing the shelf-life of meat and meat products.

\section{Acknowledgements}

The research was supported by the Brain Korean 21 Plus (BK 21 Plus) Project from Ministry of Education and $\mathrm{Hu}-$ man Resources Development (Republic of Korea). The authors also were partially supported (608001-05-2-SB 310) by Rural Development Administration (Republic of Korea).

\section{References}

1. AOAC (2009) Official methods of analysis of AOAC. $18^{\text {th }}$ ed, Association of Official Analytical Chemists, Washington, DC.

2. Baydar, H., Sağdiç, O., Gülcan, Ö., and Karadoğan, T. (2004) Antimicrobial activity and composition of essential oils from Origanum, Thymbra and Satureja species with commercial importance in Turkey. Food Control. 15, 169-172.

3. Bonoli, M., Caboni, M. F., Rodriguez-Estrada, M. T., and Lercker, G. (2007) Effect of feeding fat sources on the quality and composition of lipids of precooked ready-to-eat fried chicken patties. Food Chem. 101, 1327-1337.

4. Campo, M. M., Nute, G. R., Hughes, S. I., Enser, M., Wood, J. D., and Richardson. R. I. (2006) Flavour perception of oxidation in beef. Meat Sci. 72, 303-311.

5. Carpenter, R., O'Grady, M. N., O'Callaghan, Y. C., O'Brien, N. M., and Kerry, J. P. (2007) Evaluation of the antioxidant potential of grape seed and bearberry extracts in raw and cooked pork. Meat Sci. 76, 604-610.

6. Choi, Y. S., Choi, J. H., Han, D. J., Kim, H. Y., Lee, M. A., Kim, H. W., Jeong, J. Y., and Kim, C. J. (2011) Effects of rice bran fiber on heat-induced gel prepared with pork salt-soluble meat proteins in model system. Meat Sci. 88, 59-66.

7. Chouliara, E., Karatapanis, A., Savvaidis, I. N., and Kontominas, M. G. (2007) Combined effect of oregano essential oil and modified atmosphere packaging on shelf-life extension of fresh chicken breast meat, stored at $4^{\circ} \mathrm{C}$. Food Microbiol. 24, 607-617.

8. Djenane, D., Sánchez-Escalante, A., Beltran, J. A., and Roncalés, P. (2002) Ability of $\alpha$-tocopherol, taurine and rosemary, in combination with vitamin $\mathrm{C}$, to increase the oxidative stability of beef steaks packaged in modified atmosphere. Food Chem. 76, 407-415.

9. Donald, S. M. (1998) Flavor formation in meat and meat products: A review. Food Chem. 62, 415-424.

10. Folch, J., Lee, M., and Stanley, S. G. H. (1957) A simple method for the isolation and purification of total lipids from animal tissues. J. Biol. Chem. 226, 497-509.

11. Grigelmo-Miguel, N., Abadýìas-Serós, M. I., and MartýìnBelloso, O. (1999) Characterisation of low-fat high-dietary fibre frankfurters. Meat Sci. 52, 247-256.

12. Hassan, O. and Fan. L. S. (2005) The anti-oxidation potential of polyphenol extract from cocoa leaves on mechanically deboned chicken meat (MDCM). Food Sci. Technol. 38, 315321.

13. Hwang, K. E., Choi, Y. S., Choi, J. H., Kim, H. Y., Lee, M. A., Kim, H. W., Chung, H. K., and Kim, C. J. (2011) The antioxidative properties of Ganghwayakssuk (Artemisia princeps Pamp.) extracts added to refrigerated raw chicken nugget batter against lipid oxidation. Korean J. Food Sci. An. 31, 166175.

14. Juntachote, J., Berghofer, E., Siebenhandl, S., and Bauer, F. (2006) The antioxidative properties of holy basil and galangal in cooked ground pork. Meat Sci. 72, 446-456.

15. Kim, Y. J. (2011) Effect of the addition method of mugwort on antioxidant effect, total plate counts, and residual nitrite content of emulsified sausages during cold storage. Korean J. Food Sci. An. 31, 122-128.

16. Lawless, H. T. and Heymann. H. (1999) Sensory evaluation of food principles and practices. Springer Science + Business Media, NY, pp. 450-457

17. Liz. K. L. K. and Getty K. J. K. (2013) Natural antioxidants in meat and poultry products: A review. Meat Sci. 94, 220227.

18. López-López, I., Cofrades, S., and Jiménez-Colmenero, F. (2009) Low-fat frankfurters enriched with $n-3$ PUFA and edible seaweed: effects of olive oil and chilled storage on physicochemical, sensory and microbial characteristics. Meat Sci. 83, 148-154.

19. Luciano, G., Monahan, F. J., Vasta, V., Pennisi, P., Bella, M., and Priolo, A. (2009) Lipid and colour stability of meat from lambs fed fresh herbage or concentrate. Meat Sci. 82, 193199.

20. Melton, S. L. (1983) Methodology for following lipid oxidation in muscle foods. Food Technol. 37, 105-111.

21. Mexis, S. F., Chouliara, E., and Kontominas, M. G. (2009) Combined effect of an $\mathrm{O}_{2}$ absorber and oregano essential oil on shelf-life extension of Greek cod roe paste (tarama salad) stored at $4^{\circ}$ C. Inno. Food Sci. Emer. Technol. 4, 572-579.

22. Nassu, R. T., Gonçalves, L. A., Pereira da Silva, M. A., and Beserra, F. J. (2003) Oxidative stability of fermented goat meat sausage with different levels of natural antioxidant. Meat Sci. 63, 43-49.

23. Naveena, B. M., Sen, A. R., Vaithiyanathan, S., Babji, Y., and Kondaiah, N. (2008) Comparative efficacy of pomegranate juice, pomegranate rind powder extract and BHT as antioxidants in cooked chicken patties. Meat Sci. 80, 1304-1308. 
24. Qi, S. and Zhou. D. (2013) Lotus seed epicarp extract as potential antioxidant and anti-obesity additive in Chinese Cantonese sausage. Meat Sci. 93, 257-262.

25. Sampaio, G. R., Saldanha, T., Soares, R. A., and Torres, E. A. (2012) Effect of natural antioxidant combinations on lipid oxidation in cooked chicken meat during refrigerated storage. Food Chem. 135, 1383-1390.

26. Sánchez-Escalante, A., Djenane, D., Torrescano, G., Beltrán, J. A., and Roncales, P. (2003) Antioxidant action of borage, rosemary, oregano, and ascorbic acid in beef patties packaged in modified atmosphere. J. Food Sci. 68, 339-344.

27. Sheu, K. S. and Chen. T. C. (2002). Yield and quality charac- teristics of edible broiler skin fat as obtained from five rendering methods. J. Food Eng. 55, 263-269.

28. Tarladgis, B. G., Watts, B. M., Younthan, M. T., and Dugan, L. R. (1960) A distillation method for the quantitative determination of malonaldehyde in rancid foods. J. Am. Oil Chem. Soc. 37, 403-406.

29. Velioglu, Y. S., Nazza, G., Gao, L., and Oomah, B. D. (1998) Antioxidant activity and total phenolics in selected fruits, vegetables and grain products. J. Agric. Food Chem. 46, 41134117.

(Received 2014.4.16/Revised 2014.6.13/Accepted 2014.7.10) 